Commentary

\title{
Exposure to inorganic arsenic from rice: A global health issue?
}

\author{
Yong-Guan Zhu ${ }^{\mathrm{a}, \mathrm{b}, *}$, Paul N Williams ${ }^{\mathrm{a}, \mathrm{c}}$, Andrew A Meharg ${ }^{\mathrm{c}, * *}$ \\ ${ }^{a}$ Research Center for Eco-environmental Sciences, Chinese Academy of Sciences, 18 Shuangqing Road, Beijing 100085, China \\ ${ }^{\mathrm{b}}$ Institute of Urban Environment, Chinese Academy of Sciences, Xiamen 361003, China \\ ${ }^{\mathrm{c}}$ School of Biological Sciences, University of Aberdeen, Cruickshank Building, St Machar Drive, Aberdeen AB24 $3 U U$, UK
}

\section{A R T I C L E I N F O}

\section{Article history:}

Received 26 March 2008

Accepted 27 March 2008

\section{Keywords:}

Arsenic

Rice

Health

Cancer

Worldwide concerns over inorganic arsenic $\left(\mathrm{As}_{\mathrm{i}}\right)$ in potable water have prompted much research and policy development focusing on removing this chronic human carcinogen (Nordstrom, 2002; Ahmed et al., 2006). However, recent studies have indicated that elevated $A s_{i}$ in rice may additionally contribute significantly to dietary $A s_{i}$ intake (Heikens, 2006). Around $50 \%$ of total As in grain is $A s_{i}$, although this can vary from 10 to $90 \%$, with the remainder being dimethylarsononic acid (DMA) (Heikens, 2006). The risk posed by dietary As normally focuses on $\mathrm{As}_{\mathrm{i}}$ as this is the carcinogenic component with a linear dose response for chronic exposure (NRC, 2001). Rice is by far the largest food dietary source of $\mathrm{As}_{\mathrm{i}}$ for populations not drinking water with elevated As (Meacher et al., 2002; Tsuji et al., 2007).

Globally, over 400 million metric tons of milled rice is consumed each year (Ricestat, 2007), which accounts for nearly 50\% of total cereal consumption, with approximately half of the world's population reliant upon it for sustenance (FAOSTAT, 2007). Global requirements for rice continue to increase, and will likely lead to the expansion of rice production to meet this demand.

Rice is particularly susceptible to As accumulation compared to other cereals as it is generally grown under flooded conditions where As mobility is high (Heikens, 2006). Baseline levels of As are

\footnotetext{
is Responses to this commentary are encouraged and are most welcome. Please send responses as Response to Commentary and send via EES (http://ees.elsevier. com/envpol).

* Corresponding author. Research Center for Eco-environmental Sciences, Chinese Academy of Sciences, 18 Shuangqing Road, Beijing 100085, China.

** Corresponding author.

E-mail addresses: ygzhu@rcees.ac.cn (Y.-G. Zhu), a.meharg@abdn.ac.uk (A.A Meharg).
}

$\sim 10$-fold higher than other cereal grains (Williams et al., 2007), with baseline levels of $A s_{i}$ being of concern (Meharg et al., submitted for publication). This is greatly exacerbated by As contamination of rice production systems from a myriad of sources including irrigation with As-tainted groundwaters, mineral exploration and processing industries, and As pesticide use (Liu et al., 2005; Lee et al., 2008). For example, rice grown in elevated paddy soils of both Bangladesh and USA have arsenic levels threefold higher than baseline. Between different growing regions/countries total As content can vary by fivefold, with Himalayan (N. India, N. Pakistan, and Nepal) rice being the lowest and US, EU and As-groundwater impacted Bangladesh rice being the highest (Heikens, 2006; Meharg et al., submitted for publication).

Legally enforceable maximum contaminant levels (MCL) for $\mathrm{As}_{\mathrm{i}}$ in drinking water of $10 \mu \mathrm{g} / \mathrm{L}$ have been adopted by most countries that can afford compliance costs, such as in the EU, US and China. Based on US lifetime average daily drinking water consumption rate of $1 \mathrm{~L}$ (NRC, 2001), As $\mathrm{s}_{\mathrm{i}}$ exposure at the MCL would equate to a daily exposure of $10 \mu \mathrm{g}$. For frequent rice consumers, especially pertinent to typical Asian diets, $200 \mathrm{~g} / \mathrm{d}$ dry weight of rice or rice products (i.e. rice noodle) is not uncommon. Indeed, for rice subsistence diets average daily consumption can range from $\sim 200-900 \mathrm{~g} / \mathrm{d}$. The bioavailability of $A s_{i}$ in rice has been shown to be high (Juhasz et al., 2006) therefore grain concentration in rice would have to be as low as $50 \mu \mathrm{g} / \mathrm{kg}$ if consumed at $200 \mathrm{~g} / \mathrm{d}$ to equate to similar exposures from drinking water at $10 \mu \mathrm{g} / \mathrm{L}$. Incidentally, the levels of total arsenic found normally in upland cereals such as wheat and barley are generally less than $50 \mu \mathrm{g} / \mathrm{kg}$ (Williams et al., 2007). However, a summary of rice speciation data from the literature shows rice to commonly exceed $A s_{i}$ concentrations of $50 \mu \mathrm{g} / \mathrm{kg}$ reaching levels up to $\sim 400 \mu \mathrm{g} / \mathrm{kg}$ (Heikens, 2006).

While $A s_{i}$ in water is highly regulated internationally, food $A s_{i}$ has received much less attention. There are no EU, US or WHO limits for either total As or $\mathrm{As}_{\mathrm{i}}$ in food (Francesconi, 2007). China has one of the most stringent regulations for As in rice, with maximum contaminant levels (MCLs) of $150 \mu \mathrm{g} \mathrm{As} / \mathrm{kg}$. Yet, exposure to $A s_{i}$ from typical rice ingestion rates by farmers in parts of southern China of 400-500 g per day at $150 \mu \mathrm{g} \mathrm{As} / \mathrm{kg}$ equates to the consumption of $6 \mathrm{~L}$ of water at the Chinese drinking water MCL $(10 \mu \mathrm{g} / \mathrm{L})$. Considering global rice consumption rankings for daily ingestion China comes only 17 th in the world.

The risk of $A s_{i}$ exposure from rice must not just be considered in the context of Asian communities. Infants and young children of all 
ethnicities generally have higher exposures to $A s_{i}$ via rice than for adults when considered on a body mass basis (Meharg et al., 2008a). Research has shown the need for increased vigilance to As exposure during critical periods in children's development (Vahter, 2008), with resulting long term health and development issues arising from intrauterine and early childhood exposures to $A s_{i}$, often being undetectable at first only to manifest later in life (Vahter, 2008). With this in mind, rice as an exposure source of As must be considered more seriously. We were therefore alarmed to discover that in many countries, a potential new source of dietary As exposure was emerging.

Rice based products are marketed as healthy functional or "super" foods such as stabilized bran flour and bran solubles, rice bran that has been heat treated to prolong shelf-life and then enzymatically extracted to collect water soluble components. Newly published data have for the first time shown that brown (unpolished) rice has in fact higher levels of both total As and $A s_{i}$ than white (polished) rice, due to the localisation of $A s_{i}$ in the bran layer (Meharg et al., 2008b). We have found that commercially bought rice bran products from the US and Japan (excluding bran derived oils) directly intended for human consumption can contain up to $2000 \mu \mathrm{g} / \mathrm{kg}$ of $A s_{\mathrm{i}}$, and are typically over $1000 \mu \mathrm{g} / \mathrm{kg}$ (Sun et al., in press). Even pure untreated bran may still contain levels approaching $1000 \mu \mathrm{g} / \mathrm{kg}$. It is unlikely that consumers of these products are aware of the dietary $\mathrm{As}_{\mathrm{i}}$ that they are being exposed to when conforming to manufactures daily ingestion rates, in some cases $17 \mathrm{~g}$ per serving equating to $34 \mathrm{As}_{\mathrm{i}} \mu \mathrm{g} / \mathrm{d}$ intake at $2000 \mu \mathrm{g} / \mathrm{kg}$ of $\mathrm{As}_{\mathrm{i}}$ in bran solubles.

The findings discussed here have a terrible irony for the health conscious diet with dairy avoidance and a dependence on wholemeal foods, which can lead to a greatly increased exposure to a chronic exposure carcinogen - $\mathrm{As}_{\mathrm{i}}$. Vegan and macrobiotic diets are of particular concern. Macrobiotic diet sheets have brown rice (including rice noodles and breads) as the carbohydrate basis to 2-3 meals per day, whilst also using rice based condiments (miso, mirin, and rice wine), and rice milk or amazake (fermented rice drink) on cereals and puddings. Rice malt is used as a sugar replacement, finding its way into sweets and chocolates.

More widely available than rice bran or rice bran solubles is rice milk, a cow milk alternative. We have found that all commercial rice milk available in the UK fail EU drinking water standards $(10 \mu \mathrm{g} / \mathrm{L}$ total As), and that the vast majority of samples fail US drinking water standards $\left(10 \mu \mathrm{g} / \mathrm{L} \mathrm{As}_{\mathrm{i}}\right.$ ) (Meharg et al., 2008c). It is a moot point whether rice milk is a water substitute (i.e. water flavoured with rice) or a food, which in any case only highlights the discrepancy between water and food regulations.

Unlike As in water, arsenic in rice can hardly be removed once it is incorporated into the grain, though cooking rice in high volumes of As free water may help, but at a cost of removing vitamins. Tackling and solving dietary exposure to $A s_{i}$ at the rice source is feasible. Pragmatically, for countries largely dependent on rice imports, low $A s_{i}$ rice can be sourced from appropriate regions. For those countries with rice based agriculture where $\mathrm{As}_{\mathrm{i}}$ in this is high, the solution needs more thought. If paddy rice can be grown under more aerobic conditions, for at least part of the growing season, As content can be reduced (Heikens, 2006; Duxbury and Panaullah, 2007). This is especially true in parts of the world that irrigate rice with arsenic tainted tubewell water during dry season production such as West Bengal (India) and Bangladesh (Heikens, 2006; Duxbury and Panaullah, 2007). As highlighted in a recent report from the United Nations (Duxbury and Panaullah, 2007), one option to mitigate the impacts of irrigation with As contaminated waters is to avoid rice during the dry season, alternating with upland crops that require reduced water inputs. Even simple management strategies such as water conservation and growing rice in raised beds have been shown as potential mitigation tools in reducing

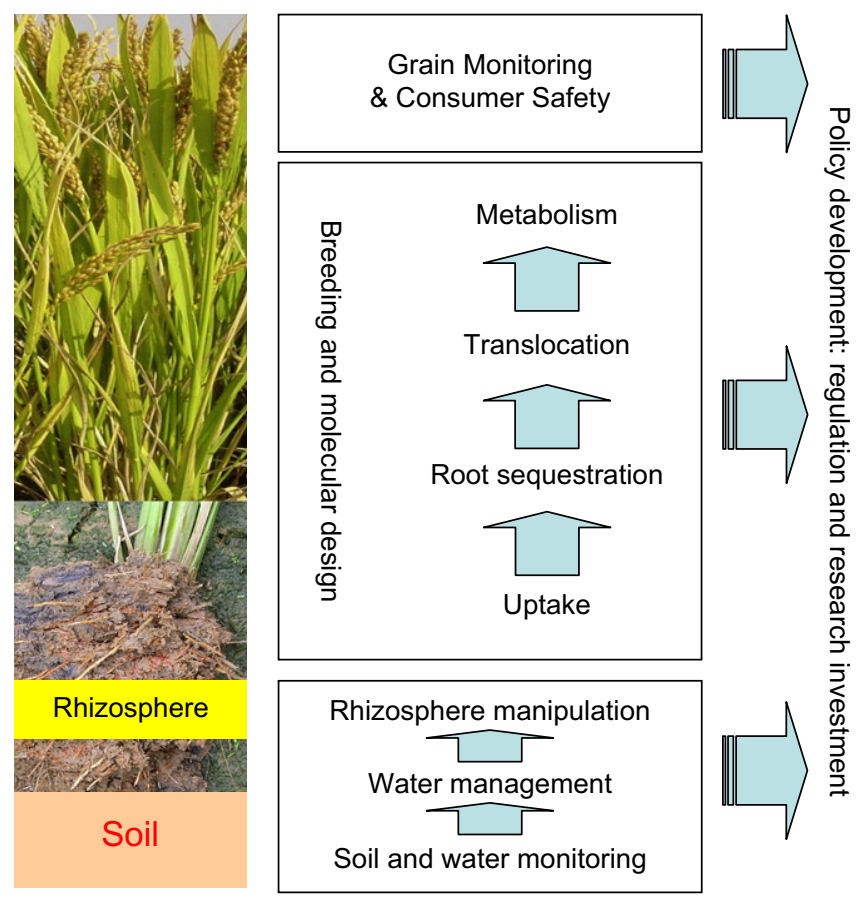

Fig. 1. Ensuring levels of $A s_{i}$ in rice are safe for all.

grain As levels during dry season production. However, converting all rice paddies into aerobic systems is neither feasible nor practical.

Breeding rice cultivars with low grain As is promising, as concentrations vary considerably between cultivars and the new discovery of quantitive trait loci associated with As accumulation has progressed the quest to identify the key genes that determine in planta arsenic assimilation (Zhang et al., 2007). Molecular approaches may also help decipher the mechanisms of arsenic speciation, allowing for the conversion of inorganic to less toxic organic forms. Curtailing As transfer into rice roots can also be achieved by manipulation of the rhizosphere, in particular zones of Fe enrichment that surround rice roots can be used to trap As (Heikens, 2006; Liu et al., 2005). However, underpinning all technological advances a clear monitoring and legislative policy must also be evident. This should encompass all aspects of rice production from soil and water management through to processing and rice consumption (Fig. 1). As pressures increase on cereal production, more and more land unsuitable for arable cultivation will start to be utilised, even maintaining As grain levels at the present status quo is a challenge in many regions of the world.

It is the rural poor in Asia, South America and perhaps continental Africa that will likely suffer most from the contamination of rice by As. In addition, if production yields are also affected as As species are phytotoxins, then a downward spiral of increased poverty and ill health could be what subsistence rice farmers might have no other option but to endure if science and policy ignore this issue.

\section{Acknowledgements}

This is study is supported by the Natural Science Foundation of China (20720102042) and The Royal Soceities of London and Edinburgh, UK.

\section{References}

Ahmed, M.F., Ahuja, S., Alauddin, M., Hug, S.J., Lloyd, J.R., Pfaff, A., Pichler, T. Saltikov, C., Stute, M., van Geen, A., 2006. Ensuring safe drinking water in Bangladesh. Science 314, 1687-1688. 
Duxbury, J.M., Panaullah, G., 2007. Remediation of Arsenic for Agriculture Sustainability, Food Security and Health in Bangladesh. Food and Agricultural Organization of the United Nations.

FAOSTAT, 2007. Food and Agriculture Organization of the United Nations. http:// faostat.fao.org/ (accessed Jan 2008).

Francesconi, K.A., 2007. Toxic metal species and food regulations - making a healthy choice. The Analyst 132, 17-20.

Heikens, A., 2006. Arsenic Contamination of Irrigation Water, Soil and Crops in Bangladesh: Risk Implications for Sustainable Agriculture and Food Safety in Asia. Food and Agricultural Organization of the United Nations, Regional Office for Asia and the Pacific.

Juhasz, A.L., Smith, E., Weber, J., Rees, M., Rofe, A., Kuchel, T., Sansom, L., Naidu, R. 2006. In vivo assessment of arsenic bioavailability in rice and its significance for human health risk assessment. Environmental Health Perspectives 114, $1826-1831$.

Lee, J.S., Lee, S.W., Chon, H.T., Kim, K.W., 2008. Evaluation of human exposure to arsenic due to rice ingestion in the vicinity of abandoned Myungbong $\mathrm{Au}-\mathrm{Ag}$ mine site, Korea. Journal of Geochemical Exploration 96, 231-235.

Liu, H.Y., Probst, A., Liao, B.H., 2005. Metal contamination of soils and crops affected by the Chenzhou lead/zinc mine spill (Hunan, China). Science of the Total Environment 339, 153.

Meacher, D.M., Menzel, D.B., Dillencourt, M.D., Bic, L.F., Schoof, R.A., Yost, L.J., Eickhoff, J.C., Farr, C.H., 2002. Estimation of multimedia inorganic arsenic intake in the US population. Human and Ecological Risk Assessment 8, 1697-1721.

Meharg, A.A., Williams, P.N., Adamako, E., Lawgali, Y.Y., Deacon, C., Villada, A., Cambell, R.C.J., Carey, A.-M., Sun, G.-X., Feldmann, J., Raab, A., Zhao, F.J., Islam, R. Hossain, S., Yanai, J., Zhu, Y.-G. Cancer risks posed by baseline inorganic arsenic contents in polished (white) market rice provide rational for revisiting food arsenic standards, Science of the Total Environment, submitted for publication.
Meharg, A.A., Sun, G.-X., Williams, P.N., Adamako, E., Deacon, C., Zhu, Y.-G., Feldmann, J., Raab, A., 2008a. Inorganic arsenic levels in baby rice are of concern. Environmental Pollution 152 (3), 746-749.

Meharg, A.A., Lombi, E., Williams, P.N., Scheckel, K.G., Feldmann, J., Raab, A., Zhu, Y.-G., Islam, R., 2008b. Speciation and localization of arsenic in white and brown rice grains. Environmental Science \& Technology 42, 1051-1057.

Meharg, A.A., Deacon, C., Campbell, R.C.J., Carey, A.-M., Williams, P.N., Feldmann, J., Raab, A., 2008c. Inorganic arsenic levels in rice milk exceed EU and US drinking water standards. Journal of Environmental Monitoring 10, 428-431.

National Research Council, 2001. Arsenic in Drinking Water - 2001 Update. National Academy Press, Washington, D.C

Nordstrom, D.K., 2002. Worldwide occurrences of arsenic in groundwaters. Science 296, 2143-2144.

Ricestat, 2007. IRRI. http://www.irri.org/science/ricestat/index.asp (accessed Jan 2008).

Sun, G-X., Williams, P.N., Deacon, C., Carey, A.-M., Raab, A., Feldmann, J, Meharg, A.A. in press. Survey of arsenic and its speciation in rice products: very high inorganic arsenic concentrations in solid rice bran products.

Tsuji, J.S., Yost, L.J., Barraj, L.M., Scrafford, C.G., Mink, P.J., 2007. Use of background inorganic arsenic exposures to provide perspective on risk assessment results. Regulatory Toxicological Pharmacology 48, 59-68.

Vahter, M., 2008. Health effects of early life exposure to arsenic. Basic \& Clinical Pharmacology \& Toxicology 102, 204-211.

Williams, P.N. Villada, A., Deacon, C., Raab, A, Figuerola, J., Green, A.J., Feldmann, J. Meharg, A.A., 2007. Greatly enhanced arsenic shoot assimilation in rice leads to elevated grain levels compared to wheat and barley. Environmental Science \& Technology 41, 6854-6859.

Zhang, J., Zhu, Y.-G., Zeng, D.-L., Cheng, W.-D., Qian, Q., Duan, G.-L., 2007. Mapping quantitative trait loci associated with arsenic accumulation in rice (Oryza sativa). New Phytologist 177, 350-355 